\title{
Contradictory Significations of the Audio-Spatial Signs in Tom Stoppard's Every Good Boy Deserves Favor:
}

A Semiotic-Cognitive Approach

Ayman F. Khafaga

(Faculty of Arts, Suez Canal University)

\section{Abstract}

This paper investigates the contradictory significations of the audiospatial signs in Tom Stoppard's Every Good Boy Deserves Favor. Four linguistic signs with their inconsistent semiotic meanings are examined in this paper: Cell, School, Office and Music. This paper addresses one research question: How does Stoppard shift the semiotic focus of the four selected signs from their schematic encoded meanings towards new contradictory significations? The main objective of the paper is to explore the extent to which the significations of the four selected signs, within particular contexts, can be reallocated to assign new meanings that run counter to their cognitive framework. The paper draws on two approaches: The first is the semiotic approach developed by Ferdinand de Saussure (1916/ 1959) and Charles Peirce (1931-1958). The second is van Dijk's (2008, 2009b) socio-cognitive approach .This paper has two main findings: First, Stoppard manages to rebalance the semiotic interpretative nature of the selected audio-spatial signs away from their schematic focus towards new specific contradiction-oriented significations. Second, Stoppard creates a cognitive connection between the play's character-to-character level of discourse, motivated by a dexterous use of some contextualization cues, and the play's intended message on the author-to-reader level of discourse, supported by the reader's cognitive ability to grasp the play's communicative context pertaining to the contradictory significations of each linguistic sign.

Keywords: significations; audio-spatial signs; semiotic-cognitive approach; Stoppard's Every Good Boy Deserves Favor

\begin{tabular}{lllll}
\hline \hline ELLS Vol. No.I & (13) SPU December 2018
\end{tabular}




\section{Contradictory Significations of the Audio-Spatial Signs in Tom Stoppard's Every Good Boy Deserves Favor: A Semiotic-Cognitive Approach Ayman F. Khafaga (Faculty of Arts, Suez Canal University)}

\section{Introduction}

Identifying the thematic message of any literary genre, specifically the conversational, is not constituted only by the communicative dialogue on its character-to-character/author-toreader levels of discourse. However, there are other elements that are crucial in forming the overall meaning of any text. Among these elements, as noted by Esslin (1987), are "the language of the dialogue, the setting, the gestures, the costumes, make-up and voice inflection of the actors, as well as a multitude of other signs" (p. 16, my emphasis). Esslin clarifies that these elements are perceived as signs incorporated in dramatic performances and "each in their own way contributes to the creation of the meaning of the performance" (ibid., p. 16). In this regard, Whitmore (1994) also states that any dramatic performance is characterized by the employment of some signs that are used to communicate meanings.

Setting is one fundamental element in drama. To Simpson (1997, p. 135), setting means not only "the non-linguistic context which envelops a piece of communication," but "the assumptions and beliefs that people bring to discourse" as well. Setting can be spatial, which constitutes not only the geographical space, but also the ideological background of the characters involved; temporal, which reflects the time when events take place; or audible, which accompanies its performance on the stage and is often reflected, parenthetically, on page. Within its audio-spatial dimensions, setting "functions as a system which generates meaning" (Fischer-Lichte,

\begin{tabular}{llllll}
\hline ELLS Vol.9 No.I (14) SPU December 2018
\end{tabular}


1992, p. 93) and, therefore, is considered to be one decisive element in creating and communicating meaning in literary genres, in general and conversational ones, in particular. Tom Stoppard's Every Good Boy Deserves Favor (henceforth EGBDF) is no exception. The play, which Stoppard subtitled as "a play for actors and orchestra" (EGBDF, P. 5), is set around three places: a Cell (in a mental hospital), a School and an Office, and is also characterized by its rich musical setting. The dramatic dialogue set in these four audio-spatial signs (i.e. Cell, School, Office and Music) has been contextualized to reflect the main themes of the play. This is conducted by attributing some contradictory significations to them that run counter to their cognitively preconceived meanings. This paper tries to shed light on the way the four audio-spatial signs exceed their schematic framework to signify other contradictory significations that serve the intended message of the play.

The present paper draws on two approaches to analyze the selected data: The first is the semiotic approach espoused by the Swiss linguist Ferdinand de Saussure (1916/1959) and the American philosopher Charles Peirce (1931-1958). The second is van Dijk's socio-cognitive approach (2008, 2009b), specifically his argument concerning global meanings of discourse, or what he terms "macrostructures" (van Dijk, 1980, p. v). Applying these two approaches helps to answer the main research question of this paper: How does Stoppard manage to attribute specific conflicting significations to the four selected signs throughout the dramatic dialogue of the play? The main objective of this paper, therefore, is to explore the extent to which significations of linguistic signs can be contextually motivated to invite different interpretations to their ingrained cognitive meanings.

The application of a semiotic-cognitive approach to the study of the audio-spatial significations of signs in literary genres allows readers the latitude to understand the different ways a linguistic sign

\begin{tabular}{lllll}
\hline \hline ELS Vol. No.I & (15) SPU December 2018
\end{tabular}


can be interpreted in texts, which facilitates the whole process of meaning-making. This correlates with Elam (2005) who perceives semiotics as "a science dedicated to the study of the production of meaning in society" and, thus, for him, "is equally concerned with processes of signification and with those of communication"; that is, "the means whereby meanings are both generated and exchanged" (p. 1, emphasis in original). As such, the reader who has the ability to grasp the different significations a sign communicates in a text is also able to seize the explicit and the implicit meanings of such a text and the intended message of its writer. In the case of the present paper, comprehending the specific (not the general) significations of the audio-spatial signs in Stoppard's EGBDF helps to understand the semiotically oriented message of the play, i.e. its political and moral themes (macrostructures).

This paper is divided into six sections: Section one is the current introduction. Section two presents the literature review of the paper and is divided into five subsections: the first three subsections review a theoretical background to the semiotic approach of de Saussure and Peirce as well as van Dijk's sociocognitive approach. Subsection four offers the theoretical framework of the paper, focusing on Peirce's triadic model of signs. Subsection five provides some previous studies relevant to the audio-spatial semiotics. Section three proposes the methodology used in the data analysis. Section four is dedicated to the analysis of data. Section five shows the findings of the paper. Section six provides the conclusion and some recommendations for future research.

\section{Literature review}

\subsection{Semiotics: de Saussure's perspective}

Ferdinand de Saussure's perspective concerning semiotics is entirely based on his view regarding language. For him (1959),
ELLS Vol.9 No.I
(16) SPU
December 2018 
language is seen as a system consisting of a set of signs that are put together to form its overall message. He argues that these linguistic signs are "numberless" (ibid., p. 73). de Saussure laid down the foundations of a science that is concerned with the study of signs. He calls it "semiology" and defines it as "a science that studies the life of signs within society" (ibid., p. 16). Semiolgy, for de Saussure, shows "what constitutes signs" and "what laws govern them" (ibid., p. 16). He concludes that "linguistics is only a part of the general science of semiology" (ibid., p. 16).

According to de Saussure (1959, p. 66), each sign consists of two main parts: signifier and signified, where signifier refers to "the psychological imprint of the sound, the impression it makes on our senses"; and a signified is "the concept or essence" of something. He conceives the relationship between signified and signifiers to be "arbitrary in nature" (ibid., p. 78); that is, there is no connection between signifiers and signified. Crucially, for him, the arbitrary nature of signs makes language unable "to defend itself against the forces which from one moment to the next are shifting the relationship between the signified and the signifier" (ibid., p. 75).

de Saussure clarifies that "the linguistic sign unites, not a thing and a name, but a concept and a sound-image... and each recalls the other." He maintains that he replaces the terms "concept" and "sound-image" with the terms "signified" and "signifier" (de Saussure, 1959, pp. 66-67). As such, a linguistic sign, for him, is characterized by two features: the first is that it is "arbitrary," or as Silverman (1983, p. 6) reports, "the connection between its two parts is unmotivated"; and the second emphasizes "the linear nature of the signifier" (de Saussure, 1959, p. 70).

\subsection{Semiotics: Peirce's perspective}

The second figure who laid down the principles of semiotics is Charles Sanders Peirce. Peirce's (1931-1958) perspective of

\section{$\begin{array}{llllll}\text { ELLS Vo1.9 No.I } & \text { (17) SPU December } 2018\end{array}$}


semiotics differs from de Saussure's in the sense that the former focuses on the linguistic dimension of the sign, while the latter is concerned with issues of representation, signification, reference and meaning. Peirce's semiotics then can be said to be pragmatic in nature as it addresses aspects related to communication and signification that are conveyed by the sign. The sign, for Peirce, "is something which stands to somebody for something in some respect or capacity. It addresses somebody, that is, creates in the mind of that person an equivalent sign, or perhaps a more developed sign" (ibid., p. 228, my emphasis). To Merrell (2005), a Peircean sign has three main components: a representamen, an object and an interpretant. Significantly, the three components of the sign, though different in their semiotic indications, are interrelated and target one goal: sign's signification. The interactive relationship between the representamen, the object and the interpretant is described by Peirce as "semiosis" (Peirce 1931-58, 5.484), and is summarized by Merrell (2005, p. 29) as follows:

With respect to the sign, we experience the representamen. It directs our attention to the semiotic object. Then we get some sort of meaning, the interpretant, as a result of the representamen's interrelation with the semiotic object and their own interrelation with the sign's meaning.

According to Merrell (2005, p. 31), Peirce's sign has three classes: icons, indices and symbols. An icon is "a sign that interrelates with its semiotic object by virtue of some resemblance or similarity with it"; an index is "a sign that interrelates with its semiotic object through some actual or physical or imagined causal connection"; and a symbol is "a sign whose interpretation is a matter of social convention" (emphasis in original). Here, the element of conventionality beyond a sign as a symbol, in the Peircean perspective, comes to terms with de Saussure's argument that signs 
are arbitrary in nature. It is also noticeable that Peircean representamen is similar to de Saussurean signifier.

Both de Saussure's and Peirce's semiotics are based on the concept of signs, their components, nature, properties and structures. They also argue for the importance of signs in mediating meanings. This is emphasized by Hervey (1982, p. 2) who states that "the conveying of messages [meanings] by signals [signs] constitutes the prototype of the phenomenon of communication." Accordingly, semiotics, as the study of signs in both de Saussrean and Peircean perspectives, is entirely concerned with the process of creating and communicating meanings. Mingers and Willcocks (2017, p.17) also refer to the role of semiotics in discovering the social and cultural dimensions of meaning in texts when they report: "Semiotics seeks to look behind or underneath the manifest appearance of texts to reveal the underlying social and cultural structures that generate them." Communicating meanings then is the main purpose beyond using signs.

Chandler (2007) points out that the meaning of signs is not "transmitted to us" but "we [readers/listeners] actively create it according to a complex interplay of codes or conventions of which we are normally unaware" (p. 11). The meaning-making process of signs, therefore, is based on the readers' ability to understand the nature of codes into which signs are produced, received and organized. Crucially, understanding signs codes and conventions is interpretative in nature, that is, it differs from one interpreter to another according to the contextual environment in which a sign is used and the cognitive background a sign interpreter has. This flexibility of signs interpretation is also referred to by Chandler (ibid., p. 32) when he states that "the meaning of a sign is not contained within it, but arises in its interpretation." Here, Chandler comes to terms with the Peircean triadic model of signs that allows more than one interpretations for the same sign, and, thus, stresses its pragmatically-based nature. This has previously been

\begin{tabular}{llll}
\hline \hline ELS Vol.9 No.I (19) SPU December 2018
\end{tabular}


emphasized by Bruss (1978, p. 86) who states that "meaning within his [Peirce] model includes both 'reference' and (conceptual) 'sense' (or more broadly, representation and interpretation)." In this regard, Mingers and Willcocks (2017, p. 18) assume that "with semiotics we are focusing attention on the form of representation itself... and the effects that the representation has on both the production and interpretation of the content."

Proceeding with Chandler's (2007) argument that "we are surely homo significans-meaning-makers," and that this meaning-making process is conducted by "our creation and interpretation of Signs" (p. 13, emphasis in original), together with the assumption that "meaning is a semiotic notion" (Brandt \&Brandt, 2005, p. 243), it follows then that there are always meanings (significations) that can be attributed to signs. For Chandler, "signs take the form of words, images, sounds, odours, flavours, acts or objects, but such things have no intrinsic meaning and become signs only when we invest them with meaning" (ibid., p. 13). So, Chandler concludes, "anything can be a sign as long as someone interprets it as 'signifying' something -referring to or standing for something other than itself" (ibid., p. 13, emphasis in original). Chandler, therefore, emphasizes the meaningful use of signs which, for him, "is at the heart of the concerns of semiotics" (ibid., p. 13).

Accordingly, signs are open to multiple (sometimes contradictory) interpretations (significations) and also "serve ideological functions" (Chandler, 2007, p. 11). The multiple interpretations of any sign come as a result of a systematic process of contextualization that makes a sign's interpretant ready to accept more than one meaning. These new meanings are usually created by the contextual circumstances employed in any discourse community. This subjectivity of signs, i.e. their readiness to undergo different meanings, makes us claim that they are also ideologically-
ELLS Vol.9 No.I
(20) SPU
December 2018 


\section{Dr. Ayman F. Khafaga}

loaded; that is, they can carry different significations: social, political, cultural or otherwise. The ability to understand the contextual circumstances in which a sign is used, or as O'Halloran (2003, p. 10) puts it, "the activity of reading a text, and making a coherent understanding of it in line with the context," leads readers to invite different significations beyond the semiotic borders of such a sign. As such, the multiplicity of signs' signification is shaped by the contextual environment in which a sign occurs and the sociocognitive background of the interpreter. This leads us to reflect on van Dijk's socio-cognitive approach (2008, 2009b).

\section{3. van Dijk's soci-cognitive approach}

The study of cognition and its relationship with discourse and society has always been a point of discussion in van Dijk's writings (1980, 1993, 1995, 1997, 2008, 2009a, 2009b, 2014). To van Dijk (2014), cognition functions to mediate between the micro and the macro structures in social sciences. Based on the close relationship between cognition, discourse and society, van Dijk termed his model as socio-cognitive, arguing that it perceives discourse as "a form of social interaction in society" (ibid., p. 12). van Dijk's sociocognitive model provides a "multidisciplinary approach" to discourse studies that attempts to achieve "socio-political goals" (van Dijk, 1993, p. 252). This approach highlights the importance of both the social and the cognitive analysis in discourse, which is also emphasized by van Leeuwen's (2009, p. 144) argument that "discourses are recontextualizations of social practices." These social practices have a cognitive base which, in turn, affects their representations in discourse.

Within the framework of this approach, according to van Dijk (1995), discourse interpretation constitutes two main directions: the first is concerned with the analysis of the microstructures of texts, including the analysis of the different relationships between propositions on the semantic, syntactic, lexical and rhetorical levels;

\section{ELLS Vo1.9 No.I (21) SPU December 2018}


and, the second highlights the macrostructures elements of texts that involve the analysis of thematic structure of discourse. This model, therefore, can be said to fulfill the analytical gap between the linguistic and the cognitive in discourse analysis.

van Dijk (1980) highlights the importance of his sociocognitive approach in the study of global (general) structures in discourse. He argues that these global structures are "the result of very fundamental cognitive principles operating in the ways we process this kind of highly complex information from the social situation" (ibid., p. 2). Consequently, the cognitive approach has an effective role to play in understanding the meaning of global structures as it relates the whole process of interpretation to the way language users produce, receive and interpret discourse. In other words, as van Dijk postulates, "our communicative verbal interaction is determined by our interpretations and representations of social reality" (ibid., p. 2).

Consequently, van Dijk (1980) differentiates between global structures and local structures in discourse. He points out that the difference between them is "the conceptual opposition of whole versus part" (ibid., p. 3). The difference, then, is of general and specific meanings in discourse, and the way they are produced and perceived. Both global and local structures of discourse have "a cognitive base" that formulates the interpretation of discourse (van Dijk, 1980, p. 18). Local meanings, to van Dijk (2001, p. 103), "are the result of the selection made by speakers or writers in their mental models of events or their more general, socially shared beliefs." A sign, therefore, can undergo different interpretations (and of course significations) that come as a result of the cognitive ability of discourse participants to understand the communicative context of any piece of discourse. 


\subsection{Theoretical framework}

A close observation of de Saussure's perspective concerning semiotics, one can notice that he demonstrates two main things: First, he concentrates on the linguistic rather than the social dimension of the sign. Second, he emphasizes the arbitrary relationship between the signifier and the signified. These, in turn, function to narrow the analytical scope of any semiotic analysis. The different dimensions of a sign, be they social, political, cultural, or otherwise, should be analyzed in order to reveal the ideological significations a sign carries. In this regard, de Saussure's semiotic perspective may be considered to be analytically inappropriate for this paper, not because it lacks the theoretical foundations upon which a semiotic analysis can be conducted, but because its determined-theoretical principles cannot, in some research cases as is the case in the present one, cover the targeted analytical purposes of the research.

Accordingly, and for analytical purposes, Peirce's triadic model of the sign is selected to be the framework adopted here. This model, as mentioned earlier, consists of three main pillars that constitute the overall significations of a sign: a representamen, an interpretant and an object. Merrell (2005) clarifies the meaning of Peircean three semiotic elements, arguing that the representamen constitutes the sign's status in everyday talk; the object is concerned with our knowledge in terms of what a sign relates to; and the interpretant refers to the sign's meaning. The three elements are closely interrelated in a way that creates a triadic reciprocal influence among them.

This intimate interrelation between the three components of the sign makes Merrell (2005, p. 29) conclude that "a fully-fledged sign must have a representamen, a semiotic object, and an interpretant, and each of these elements must enjoy the company of the other two. If not, there is no sign." Further, it is the same intermediary

\begin{tabular}{lllll}
\hline ELLS VoI.9 No.I & (23) SPU December 2018
\end{tabular}


relation between the three components that leads to the formulation of the sign's meaning (signification). This correlation between the three components of the Peircean sign is also reported by Chandler (2007, p. 29): "The sign is a unity of what is represented (the object), how it is represented (the representamen) and how it is interpreted (the interpretant)." In this paper, Peirce's triadic model is applied to the four signs under investigation (i.e. Cell, School, Office and Music) to show how the interpretant element of each sign is shifted from its general (global) significations to its contradictory specific (local) ones.

Significantly, shifting the semiotic interpretant of the selected signs from the general to the specific is pragmatically foregrounded by a skillful process of contextualization, which, to Urciuoli (2009), is considered a significant device that can be utilized to identify the appropriate context(s) of any communicative events. This process of contextualization "involves an active process of negotiation in which participants reflexively examine the discourse as it is emerging, embedding assessments of its structure and significance in the speech itself" (Bauman\& Briggs,1990, p. 69). Consequently, discourse producers, in their attempt to attribute certain significations to the linguistic signs they used, try to create and maintain particular contexts that are linguistically and cognitively relevant to the meanings they target beyond each linguistic sign. This is conducted by using specific contextual devices that drive the cognitive background of the readers/audiences, i.e. their schemata concerning the four signs, towards the new significations a writer/speaker wants to convey.

Gumperz (1982, p. 131) calls these devices "contextualization cues," stating that a contextualization cue is "any feature of linguistic form that contributes to the signaling of contextual presuppositions" (ibid., p. 131). As such, these contextualization 
cues can be said to be concerned with creating a harmonious relativity between the sign's specific signification and its new contextualized environment. Consequently, for Gumperz (1982), there is no single context for any linguistic sign. However, different new contexts can be created for the same sign by virtue of using some contextualization cues. This is totally what this paper tries to explore; to show how semiotic significations of the selected audiospatial signs, under new contexts created by means of using certain contextualization cues, are shifted from their cognitively preconceived meanings to assign new contradictory significations.

\subsection{Previous studies}

There have been miscellaneous studies in semiotics that indirectly addressed its audio-spatial perspective. These studies have tackled semiotics and its audio-spatial side from different dimensions, including the reviewing of some theories of signification and communicative practices relative to music (Inskip et al. 2008); approaching music as a communicative multimodal discourse employed to articulate ideological discourses in society (Agawu 2009; McKerrell \& Way 2017); employing the spatial semiotic analysis to show how meanings of social spaces can be altered by changing the way these places look and the activities they practice, which, in turn, reflects the identity of both the place and its inhabitants (Shortell \& Krase 2010); addressing the social dimension of semiotics by proposing an interdisciplinary approach to socio-semiotics (Randviir 2011); discussing the semiotics of geographical space as text and in text (Lagopoulos \&Lagopoulou 2014); and introducing plastic semiotics, by focusing on the sensorial dimension of the expression that is communicated by the oppositions of certain plastic qualities, such as "sharp/smooth" and "empty/ full" (Žemaitytė 2017, p. 153).

However, two studies have been shown to be directly relevant to the current paper. The first study was presented by Gaines (2006)

\begin{tabular}{lllll}
\hline ELLS Vol. & No.I & (25) SPU December 2018
\end{tabular}


in which he explained some common situations relevant to communication and the semiotics of space. Gaines used a semiotic approach to analyze the different meanings of spatial signs and the elements governing the dimensionality of meaning pertaining to them. Gaines's study drew on Pierce's three descriptive categories of signs: firstness, secondness, and thirdness. It clarified that the consideration of a spatial sign should be based on Pierce's three categories. For example, to refute the meanings of the sign 'Room', Gaines argued, we should consider it "as it is independently of anything else" (firstness), "as it is relative to something else" (secondness), and "as mediate between two others" (thirdness) (ibid., pp. 173-174). Gaines concluded his example by stating that the meaning of the space in a room essentially depends on the extent to which other objects within the spatial sign 'Room' are relevant to the sign itself, and is interpreted according to different concerns related to such space as a semiotic sign. The basic result of Gaines's study showed that a space sign's meaning is cognitively negotiated and is necessarily based on the relevance of other things associated with the sign.

The second relevant study was presented by Griffith and Machin (2014). This study investigated the way through which music can semiotically communicate different meanings. It drew on the principles of Halliday's functional grammar, and proposed a social semiotic approach to the study of musical semiotics in an attempt to explore the extent to which social semiotics can contribute to the analysis of film music. It also clarified how composers are allowed to communicate semiotically "specific ideas, attitudes and identities through combinations of different sounds and sound qualities, by presenting them as systems of meaning rather than as lists of connotations" (ibid., p. 72). The study concluded that music, with all its components, including pitch,

\section{ELLS Vol.9 No.I \\ (26) SPU \\ December 2018}




\section{Dr. Ayman F. Khafaga}

rhythm, melody and musical notes, has its underlying features that create meaning and reveal ideologies beyond its mere performance.

Apparently, the above subsection shows that the literature on the study of the audio-spatial semiotics drew on many different theoretical frameworks. The previous studies have come to acknowledge that there are always significations pertaining to audible and spatial signs that can be decoded by virtue of a semiotic analysis. This paper, though reconciled with its previous ones that the audio-spatial signs do communicate meanings, takes the analysis a step forward to argue for the very possibility that a single sign can allocate new significations inconsistent to its encoded schematic meanings.

\section{Methodology}

\subsection{Corpus of the study}

The corpus of the present paper consists of one play written by Tom Stoppard in 1977: EGBDF. The play consists of twenty-three pages and is set around three places: a mental hospital Cell, a School and an Office. The dramatic dialogue of the play is distributed in only six characters whose conversations are woven into pairs: Alexander and Ivanov (Cell); Sacha and the Teacher (School); and the Doctor and the Colonel (Office).

There are three reasons that constitute the rationale for selecting this play in particular. First, the play witnesses a semiotic-cognitive connection between its intended message and its audio-spatial setting. Second, the dramatic dialogue set in each of the three selected spatial signs reflects the importance of space in the study of power in discourse. This is emphasized by Foucault (2002, p. 361) who postulates that "space is fundamental of any form of communal life; space is fundamental in any exercise of power." This dialogue is conversationally contextualized, i.e. by means of the use of some contextualization devices, to show how the four selected signs are

\section{ELLS Vo1.9 No.I (27) SPU December 2018}


ideologically loaded by new significations contradictory to their familiarized ones. Third, the play depends entirely on music. It is described by Stoppard to be "a work consisting of words and music" (Stoppard, 1978, 13), which emphasizes the importance of its musical setting.

\subsubsection{Stoppard's $E G B D F$ : The story}

Stoppard's $E G B D F$ is a political play that relates the atrocities committed by the Soviet Union of that day against political dissidents. According to Antakyalioglu (2006), the play reflects Stoppard's interest in politics, his fight against corruption and injustice, his concern for freedom of expression, and his criticism against the political abuse in the Soviet Union that was used to uphold a totalitarian regime. The play exposes the manner through which psychiatry had politically been abused by the former Soviet Union. It also owes much to its music setting. In this regard, Stoppard (1978, p. 5) reports that EGBDF is "'A Play for Actors and Orchestra," which "hardly indicates the extent to which the effectiveness of the whole depends on the music composed by Andre` Previn" (emphasis in original).

The play tells the story of two men who hold the same name of Alexander Ivanov. The first (referred to as Alexander) is a political prisoner, who is imprisoned for criticizing the Soviet Union's regime for putting political opponents in mental hospitals. The second man (referred to as Ivanov) is a genuine mental patient, who believes he has an orchestra that is only imaginary. Both Alexander and Ivanov share a cell in a psychiatric hospital. The play corroborates the idea that totalitarian systems are always able to reshuffle reality. Each spatial setting in the play (i.e. Cell, School, and Office) has its role in conveying the main theme of the play, i.e. the tyrannical treatment of political prisoners. Alexander has to admit that he is mad and is cured by the system in order to be 
released. However, he insists that he is neither mad nor cured, which leads the Colonel to replace the cellmates' identities to set them free at the end.

\subsection{Procedure}

The analytical procedure adopted in this paper has three dimensions. The first provides a brief discussion of the main themes (macrostructures) presented in the play (thematic distribution), and the number of scenes assigned to each selected audio-spatial sign (setting-allocation). The second offers an analysis of the general significations of the four audio-spatial signs under investigation. These general significations, in the light of this paper, are called 'out-play significations', where the focus is on the generally perceived meanings of these signs that are cognitively associated with their ordinary use. The third sheds light on the specific significations of the same four signs, which are also termed 'in-play significations', and the focus is on the contradictory dimension of significations these linguistic signs semiotically captivate throughout the selected play. This is conducted in the light of Peirce's triadic model of the sign (see Subsection 2.4), as well as a process of contextualization to the dramatic dialogue of the play. Crucially, moving between the out-play and the in-play (the general and the specific) significations of the selected signs reveals that the semiotics of any linguistic sign, be it audible, spatial, or otherwise, under particular contexts, can be challenged to undergo different significations: complementary and/or contradictory.

\section{Analysis}

Before embarking on the analysis of the contradictory significations the four selected signs have been assigned in the selected play, I shall first go through summarizing the main themes addressed in the play (van Dijk's macrostructures, 1980), how each

\section{ELLS Vol.9 No.I}

(29) SPU

December 2018 
theme is connected to one particular sign, audible or spatial, and the number of scenes allocated to each sign.

\subsection{Setting-allocation and thematic distribution}

Stoppard's $E G B D F$ has been structurally distributed into three spatial signs and is encapsulated by music throughout its dialogue. Each sign has its share of incidents. Fifteen scenes formulate the total structure of the play, where the Cell takes setting of seven scenes, five scenes are allocated to the School and three scenes are dedicated to the Office.

In the Cell, a great deal of the dialogue is run between Alexander and Ivanov whose personalities, however different, meet in some points, specifically those related to their political attitudes. Through the scenes dedicated to the Cell, Stoppard addresses one of the main themes in his play: medical institutions are used to imprison political dissidents. This theme is negotiated through two opposing ideas that summarize the relationship between the participants, and the type of discourse delivered in the Cell scenes: sanity versus insanity.

The School holds the setting for the dialogue between the Teacher, who is a female, and Sacha, where the second theme is communicated: educational institutions are employed to inculcate students into accepting the regime's ideas. Here, a contradiction in political stances is clearly noticeable; the Teacher advocates and justifies the regime's policies, whereas Sacha refuses and resists them. Accordingly, another conflicting type of discourse is conveyed: domination versus resistance.

The Office witnesses a mixture of conversations from the different characters, particularly the Doctor and the Colonel who are standing on the side of the regime. Apparently, these conversations reflect the third theme of the play: administrative institutions are

\begin{tabular}{lllll}
\hline \hline ELLS Vol.9 No.I (30) SPU December 2018
\end{tabular}


utilized to control opponents, and reveal a third contradictory type of discourse: persuasion versus manipulation.

As for the audible sign Music, it is used as "a political metaphor" (Fransen, 2003, p. 6), holds a major role in the dramatic action, and covers almost all incidents in the play. Here, again, the musical hegemony over the majority of scenes tends to channel the fourth theme of the play: recreational activities are used to communicate political ideas; a theme that reproduces a further conflicting type of discourse: compliance versus opposition. The following table summarizes setting-allocation and thematic distribution of the four audio-spatial signs in the play.

Table 1. Setting-allocation and thematic distribution in EGBDF

\begin{tabular}{|c|c|c|c|c|}
\hline $\begin{array}{l}\text { Audio- } \\
\text { spatial } \\
\text { signs }\end{array}$ & $\begin{array}{l}\text { Number } \\
\text { of scenes }\end{array}$ & $\begin{array}{l}\text { Characters } \\
\text { involved }\end{array}$ & Themes addressed & $\begin{array}{l}\text { Type of } \\
\text { discourse }\end{array}$ \\
\hline$\overline{\text { Cell }}$ & 7 & $\begin{array}{l}\text { Alexander, } \\
\text { Ivanov, Sacha, } \\
\text { Colonel and } \\
\text { Doctor }\end{array}$ & $\begin{array}{l}\text { Using medical } \\
\text { institutions to } \\
\text { imprison political } \\
\text { dissidents }\end{array}$ & $\begin{array}{l}\text { Sanity versus } \\
\text { insanity }\end{array}$ \\
\hline School & 5 & $\begin{array}{l}\text { Teacher, Sacha } \\
\text { and Doctor }\end{array}$ & $\begin{array}{l}\text { Employing } \\
\text { educational } \\
\text { institutions to } \\
\text { inculcate students }\end{array}$ & $\begin{array}{l}\text { Domination } \\
\text { versus resistance }\end{array}$ \\
\hline Office & 3 & $\begin{array}{l}\text { Ivanov } \\
\text { All characters }\end{array}$ & $\begin{array}{l}\text { Utilizing } \\
\text { administrative } \\
\text { institutions to } \\
\text { manipulate } \\
\text { opponents }\end{array}$ & $\begin{array}{l}\text { versus } \\
\text { manipulation }\end{array}$ \\
\hline Music & 10 & & $\begin{array}{l}\text { Using recreational } \\
\text { activities for political } \\
\text { purposes }\end{array}$ & $\begin{array}{l}\text { Compliance } \\
\text { versus } \\
\text { opposition }\end{array}$ \\
\hline
\end{tabular}

ELLS Vol.9 No.I

(31) $S P U$

December 2018 
As shown in table 1, the Cell dominates nearly half of the play's scenes ( 7 out of 15), whereas the rest of scenes have been allocated to the School and the Office (5, 3 out of 15 , respectively). The table also displays that the musical performance covers 10 out of 15 scenes of the play. Significantly, the number of scenes allocated to the four signs reflects two things. First, the four themes (macrostructures), addressed in the play, revolve around one major theme: governmental institutions, whether medical, educational, administrative, or otherwise, are tyrannically utilized to achieve political purposes. This also correlates with Hurst's (2016, p. 485) argument that the play "highlights the Soviet abuses through public and private channels," the main point beyond Stoppard's play. Second, there are different contradictory relationships between the different characters in the play, which cognitively foregrounds a semiotic shift in the significations of the four audio-spatial signs. Now it is time to analyze the semiotics of the four selected signs by showing what general (out-play) significations they carry and how they are contextualized to assign specific (in-play) significations.

\subsection{The semiotics of the spatial sign 'Cell'}

The first spatial sign that we meet in the play is the 'Cell', which Stoppard told us that it is a cell in a mental hospital. Consequently, the initial signification this sign conveys is that of a medical treatment. This general signification can easily be grasped since the sign 'Cell' carries the connotative meanings of a medical treatment that is offered to persons who are mentally incompetent. The following figure demonstrates the general (out-play) and the specific (in-play) significations of the sign 'Cell'.

\section{ELLS VoI.9 No.I (32) SPU December 2018}




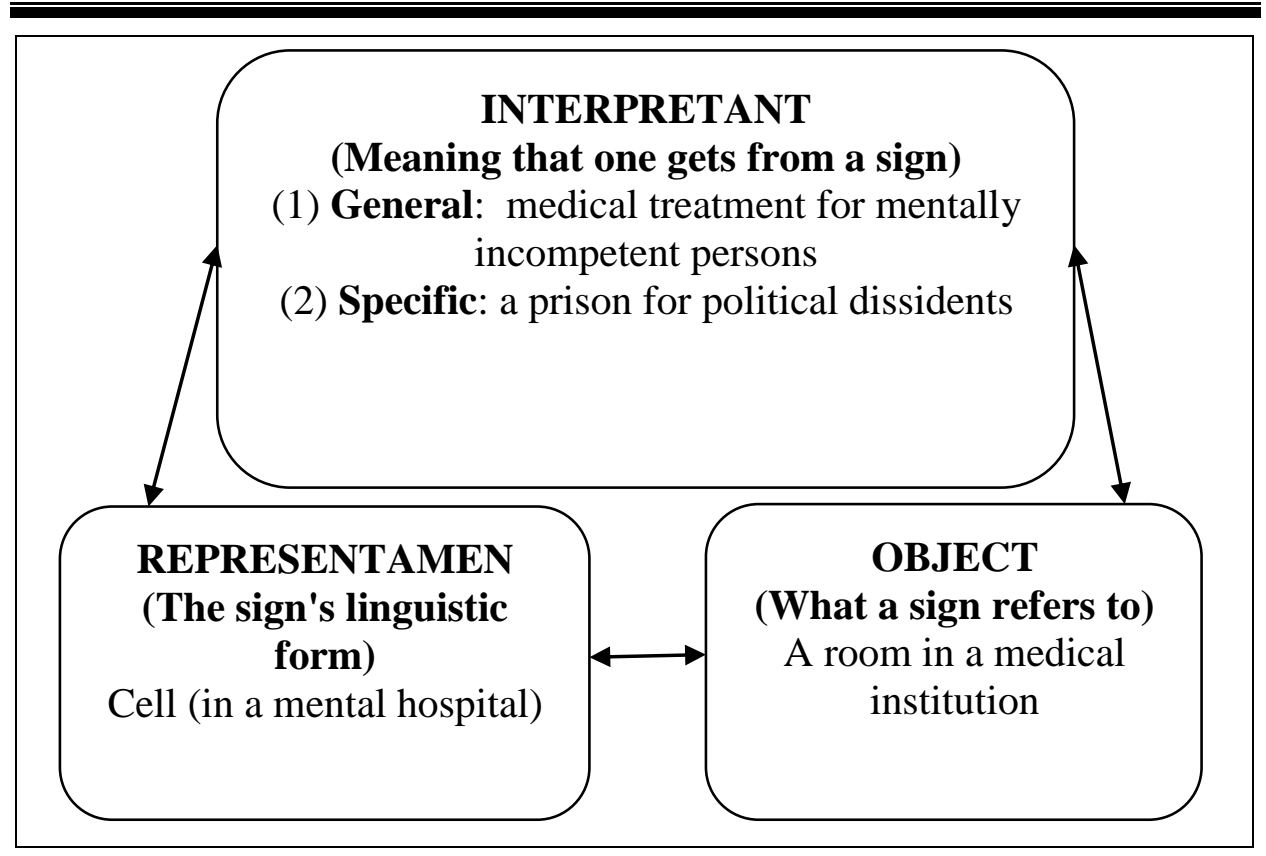

Figure 1. General/specific significations of the sign 'Cell' in Peirce's triadic model

The above figure clarifies that the significations of the sign 'Cell', within the framework of Peirce's triadic model of the sign, have three interrelated elements that represent the basic components of signs. The first component is the representamen, which means the mere linguistic form of the word 'Cell'. This linguistic representation is used for a referential purpose that constitutes the object of the sign. Here, the sign 'Cell' refers to a room in a medical institution. The third component is the interpretant, which refers to the interpretation of a sign by language users. To Peirce, this interpretation "entailed a form of 'negotiation,'... whereby the signuser evaluates or responds to what the sign means socially, contextually, personally, etc." (cited in Sebeok, 2001, p. 6). The sign 'Cell', then, entails two significations (interpretations): general (out-play) and specific (in-play). The general signification carries

\section{ELLS Vol.9 No.I}

(33)

December 2018 
the meaning of medical treatment for mentally incompetent persons, whereas the specific signification revolves around the idea of imprisonment. Noticeably, the interpretant element of the sign 'Cell' has been changed from the general to the specific. This can be easily grasped if we thoroughly investigate the dramatic dialogue of the play.

From the very beginning of the play's events, Stoppard seems to shift the readers'/audience's attention towards the specific signification of the sign 'Cell'. This is conducted by means of using some contextualization devices that function to change the semiotic wheel of the sign from the general to the specific, i.e. from its cognitively schematic meaning towards contextually-acquired significations. This dramatic contextualization is initially communicated by Alexander himself when he recounts the real purposes beyond putting people in mental hospital 'Cells':

One day they arrested a friend of mine for possessing a controversial book, and they kept him in mental hospitals for a year and a half... Soon after he got out, they arrested a couple of writers, A and B, who had published some stories abroad under different names....My friend, $\mathrm{C}$, demonstrated against the arrest of A and B. I told him he was crazy to do it, and they put him back into the mental hospital... C finished his sentence about the same time as $\mathrm{A}$, and then he did something really crazy. He started telling everybody that sane people were being put in mental hospitals for their political opinions.

(EGBDF, P. 23, my emphasis)

In the above quote, the specific significations of the sign 'Cell' are provoked by Alexander's above words through which readers can seize the new meaning pertaining to mental hospitals; they are not established for medical purposes, but for political ones. These hospitals are real prisons for those who speak or write against the

ELLS Vol.9 No.I (34) SPU December 2018


regime. Alexander tells us that his friends were put in mental hospitals for specific reasons: possessing a controversial book, publishing stories and protesting against the regime. This emphasizes that mental hospital cells, in the context of the play, have a particular purpose that contradicts their supposed targets. They cease to indicate their general significations and assign another specific meaning. This is also emphasized by Alexander's words that conclude the quote above: 'Sane people were being put in mental hospitals for their political opinions'. Importantly, Stoppard's dramatic skill to enumerate the experiences of Alexander's friends in such an organized way correlates with Hugh Rank's "intensifying/downplaying schema" (cited in Hirschberg, 1999, p. 513) that discusses some intensification techniques through which an argument is intensified and/or downplayed. One of these techniques is composition. This strategy entails that an argument gains intensity when it is arranged in a clearly perceivable pattern. This strategy of intensification, which Stoppard uses here, tends to shift the focus of his readers/audiences to what he wants them to understand, i.e. the atrocities committed against political dissidents under the pretext of mental incompetency. This also functions to bring about the specific signification of the sign 'Cell' to the cognitive realm of readers/audiences.

The same specific signification of the sign 'Cell' is motivated by Alexander when he reports: "They put me in the Leningrad Special Psychiatric Hospital on Arsenal'naya Street, where I was kept for thirty months, including two months on hunger strike" (EGBDF, P. 24). The 'two months on hunger strike' phrase indicates that Alexander was not put in the hospital for medical treatment. In fact, it was a prison not a hospital. This becomes clear when Alexander describes the place: "There are bars on the windows, peepholes in the doors, and the lights burn all night. It is run just like a gaol" (EGBDF, P. 29). Further, the type of treatment Alexander leads inside the cell highlights the specific significations assigned to this

\begin{tabular}{lllll}
\hline ELLS Vol.9 No.I & (35) SPU December 2018
\end{tabular}


sign: "They beat and humiliate the patients and steal their food, and are protected by the doctors, some of whom wear KGB uniforms under their white coats" (EGBDF, P. 29). This severe treatment reaches its climax with Alexander:

I was given injections of aminazin, sulfazin, triftazin, haloperidol and insulin, which cause swellings, cramps, headaches, trembling, fever and the loss of various abilities including the ability to read, write, sleep, sit, stand, and button my trousers...I was stripped and bound head to foot with lengths of wet canvas. As the canvas dried it became tighter and tighter until I lost consciousness. They did this to me for ten days.

(EGBDF, P. 29)

It is obvious in the above quote that the play's main focus is to expose political corruption and injustice rooted in totalitarian regimes and rests behind feigned allegations of mental illness. Crucially, Stoppard challenges the schematic knowledge of his readers/audiences regarding the semantics of the sign 'Cell' since he leaves no chance for them to attribute any supposed significations to the sign other than the political. The bad treatment of patients (political dissidents), Alexander's description of the hospital cells, together with Alexander's argument: "For the politicals, punishment and medical are intimately related" (EGBDF, P. 29) tend to form new cognitive frames on the part of the readers/audiences through which they can easily seize the in-play political significations associated with the sign 'Cell'.

\subsection{The semiotics of the spatial sign 'School'}

The spatial sign 'School' has general significations that are perceived when utilized outside the play, and specific significations attached to the sign within the contextual and dramatic atmosphere of the play. The following figure displays the two types of

\section{ELLS Vol.9 No.I}


significations attributed to the sign 'School' within the framework of Peirce's triadic model of the sign.

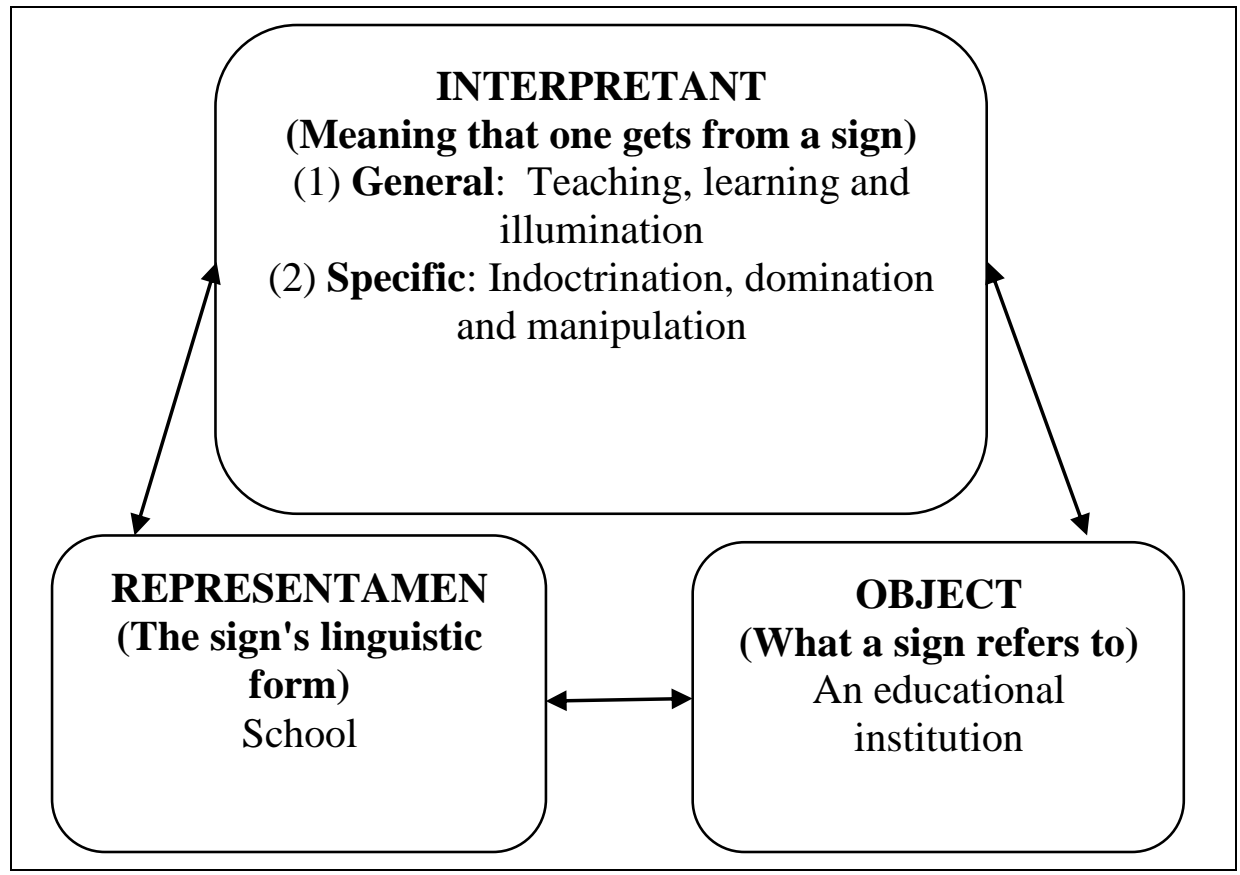

Figure 2. General/specific significations of the sign 'School' in Peirce's triadic model

As shown in the above figure, the spatial sign 'School' refers to an educational institution that represents its object. In terms of its interpretant, the sign 'School' undergoes two different significations: general and specific. The general interpretation, on the one hand, involves teaching, learning and illumination, concepts that can cognitively be attached to the sign when used outside the play, i.e. in its schematic ordinary context. The specific significations of the sign 'School', on the other hand, contradict its generally ostensible ones as they indicate concepts of domination, indoctrination and manipulation. These specific significations have been contextualized throughout the play's dialogue.

\section{$\begin{array}{lllll}\text { ELLS Vo1.9 No.I (37) SPU December } 2018 & \end{array}$}


The first situation in which the spatial sign 'School' appears to violate its ordinary significations towards contradictory ones is shown in the conversations led by Sacha (Alexander's son) and the Teacher, where the latter tries to convince the former that his father is truly ill, and thus he was put in a hospital not a prison: "It's not a prison, it's a hospital" (EGBDF, P. 20). It is obvious that both Sacha and the Teacher represent two opposite parties; one that stands on the side of the regime (Teacher) and another that represents opposition (Sacha). This ideological conflict has discursively been represented in two things: the first is the Teacher's many attempts to convince Sacha that the system is always right; the second is Sacha's resistance and defense of his own beliefs. This reveals the fact that the sign 'School' ceases to be a place where education and illumination are offered and becomes a site for power conflict, which emphasizes the contradictory dimension of its in-play signification.

The Teacher continues her manipulative task towards Sacha when she threatens him that he will have the same fate of his father: "Detention is becoming a family tradition... you see what happens to anti-socialist malcontents" (EGBDF, p. 19). She tries to intensify Sacha's father's mistakes to persuade him that his father is truly guilty: "So this is how I repaid. Is this how it began with your father? First he smashes school property. Later he keeps bad company. Finally, slanderous letters. Lies. To his superiors. To the party. To the newspaper....To foreigners" (EGBDF, P. 24). Here, by linking the concepts of lying, slander and destruction to Sacha's father, the Teacher attempts to draw Sacha's attention to the idea that makes him certain of his father's faults, which justifies the regime's act of imprisoning his father. When Sacha tries to defend his father: "Papa doesn't lie. He beat me when I did it," the Teacher hurries to confirm Alexander's faults: "Lies! Bombarding Pravda with lies! What did he expect?" (EGBDF, p. 24, emphasis in

ELLS Vol.9 No.I 
original). Now, within such an ideological conflict, the Teacher tries to convey that Alexander is put in prison because he violates the regime's rules. It is also an implicit threat to Sacha that if he does not comply with her orders, which are entirely pro-governmental, he will have the same fate of his father. Significantly, the Teacher's insistence on advocating the regime's principles reflects the extent to which educational institutions (i.e. under dictator regimes), with all their involved elements (i.e. students, teachers and textbooks), are employed to achieve political purposes.

Furthermore, the specific significations (i.e. manipulation and indoctrination) attributed to the spatial sign 'School' are channeled to the readers/audiences through the Teacher's intentional attempt to present the regime positively when she tells Sacha:

Things have changed since the bad old days. When I was a girl there were terrible excesses. A man accused like your father might well have been blameless. Now things are different. The Constitution guarantees freedom of conscience, freedom of the press, freedom of speech, of assembly, of worship and many other freedoms. The Soviet Constitution has always been the most liberal in the world, ever since the first constitution was written after the Revolution.

(EGBDF, PP. 29-30, my emphasis)

The above quote displays a comparison between the previous regime, which the Teacher describes as 'the bad old days' that witnessed 'terrible excesses'; and the present regime, which is described as an age of different types of freedoms: 'of conscience, of the press, of speech, of assembly, and of worship'. In addition, the use of the frequency adverb 'always' and the superlative form 'the most', which are utilized to describe the constitution of the present regime, attempts to reflect perfection, certitude and continuity. This, in turn, facilitates the process of Sacha's manipulation.

\section{ELLS Vol.9 No.I (39) SPU December 2018}


Proceeding with the same contextualization process to shift the semiotic focus of the sign 'School' from the general to the specific significations, Stoppard shows his readers/audiences the way through which Sacha's resists his Teacher's domination. Sacha's resistance passes through two stages: direct and indirect. The direct mode of resistance has been dramatically enabled by Sacha's direct rejection: "I don't want to be in the orchestra" (EGBDF, P. 19). A refusal that cannot be accepted by the Teacher whose main concern is to make Sacha involved in the orchestra, particularly if we know that the orchestra (music) stands for the government (which will be discussed in Subsection 5.3 below). This has been emphasized when Sacha asks his Teacher: "Is this what they make papa do?". She replies: "Yes. They make him copy, 'I am a member of an orchestra and we must play together" (EGBDF, P. 20). It is the same resistant attitude that makes Sacha refuses the Teacher's claims that his father is mentally ill when he directly says: "I don't care!- he was never sick at home. Never!" (EGBDF, P. 26).

As for the indirect mode of resistance, it manifests itself in Sacha's use of some mathematical rules during his dialogue with his teacher as follows:

Teacher: Open the book. Pencil and paper. You see what happens to anti - social malcontents.

Sacha: Will I be sent to the lunatics' prison?

Teacher: Certainly not. Read aloud.

Sacha: 'A point has position but no dimension.'

Teacher: The asylum is for malcontents who don't know what they're doing.

Sacha: 'A line has length but no breadth.'

Teacher: They know what they're doing but they don't know it's antisocial.

Sacha: 'A straight line is the shortest distance between two points.' 
Teacher: They know its anti-social but they are fanatics.

Sacha: 'A circle is the path of a point moving equidistant to a given point.'

Teacher: They're sick.

Sacha: 'A polygon is a plane area bounded by straight lines.'

Teacher: And it's not a prison, it's a hospital. (Pause) Sacha: 'A triangle is the polygon bounded by the fewest possible sides.'

(EGBDF, PP. 19-20)

As demonstrated in the above quote, Sacha's insistence on listing some mathematical rules one after another without considering his Teacher's talk is an indirect way of expressing his rejection to the Teacher's claims. Sacha's rejection to his Teacher's talk is met by her assertion that 'it's not a prison, it's a hospital', which indicates that Sacha has no way other than accepting the idea that the system is always right, that is, to be a member of the orchestra. Importantly, Sacha uses his mathematical principles to reach a logical conclusion that defends his father's status. This is clearly shown in the next scene when he employs the same argumentative manner to prove that his father was put in prison not a hospital:

Sacha: A triangle is the shortest distance between three points.

Teacher: Rubbish.

Sacha: A circle is the longest distance to the same point. Teacher: Sacha!

Sacha: A plane area bordered by high walls is a prison not a hospital. (EGBDF, PP. 25-26, my emphasis)

The last line of the above extract emphasizes Sacha's conviction that his father is imprisoned and that the government is not right as his Teacher tries to convey. Further, Sacha's resistance mode is supported by his father's words: "Dear Sacha, try to see what they call their liberty is just the freedom to agree that one and one is sometimes three" (EGBDF, p. 34). Sacha's father tries to assure him

\begin{tabular}{llll}
\hline \hline ELS Vol.9 No.I (41) SPU December 2018
\end{tabular}


not to trust the system as it tries to falsify facts. He asks his son to stick to his beliefs and not to submit to the regime's manipulative purposes: "Dear Sacha...to thine own self be true, one and one is always two" (EGBDF, P. 36).

It is important to mention here that Sacha's resistance seems to be attenuated towards the end of the play. This is conversationally clarified when he asks his father: "Papa, don't be rigid! Be brave and tell them lies! Tell them lies. Tell them they've cured you. Tell them you're grateful" (EGBDF, P. 35). Sacha's words indicate his inability to continue resisting the system. Now he wants his father to tell lies in order to be released. Here, from the semiotic space of the sign 'School', which is discursively contextualized, emerges what Brandt and Brandt (2005, p. 227) call "reference space"; that is, the different assumptions attributed to the sign when it comes to be used within a particular context. Crucially, a school, which witnesses incessant attempts of domination encountered by different forms of resistance, cannot be claimed to assign its ordinary conceptual meanings; however, such an atmosphere invites contradictory significations to the semiotics of the sign.

\subsection{The semiotics of the spatial sign 'Office'}

The 'Office' is the third spatial sign that carries specific significations contrary to its general ones. The two types of significations can be demonstrated in the following figure. 


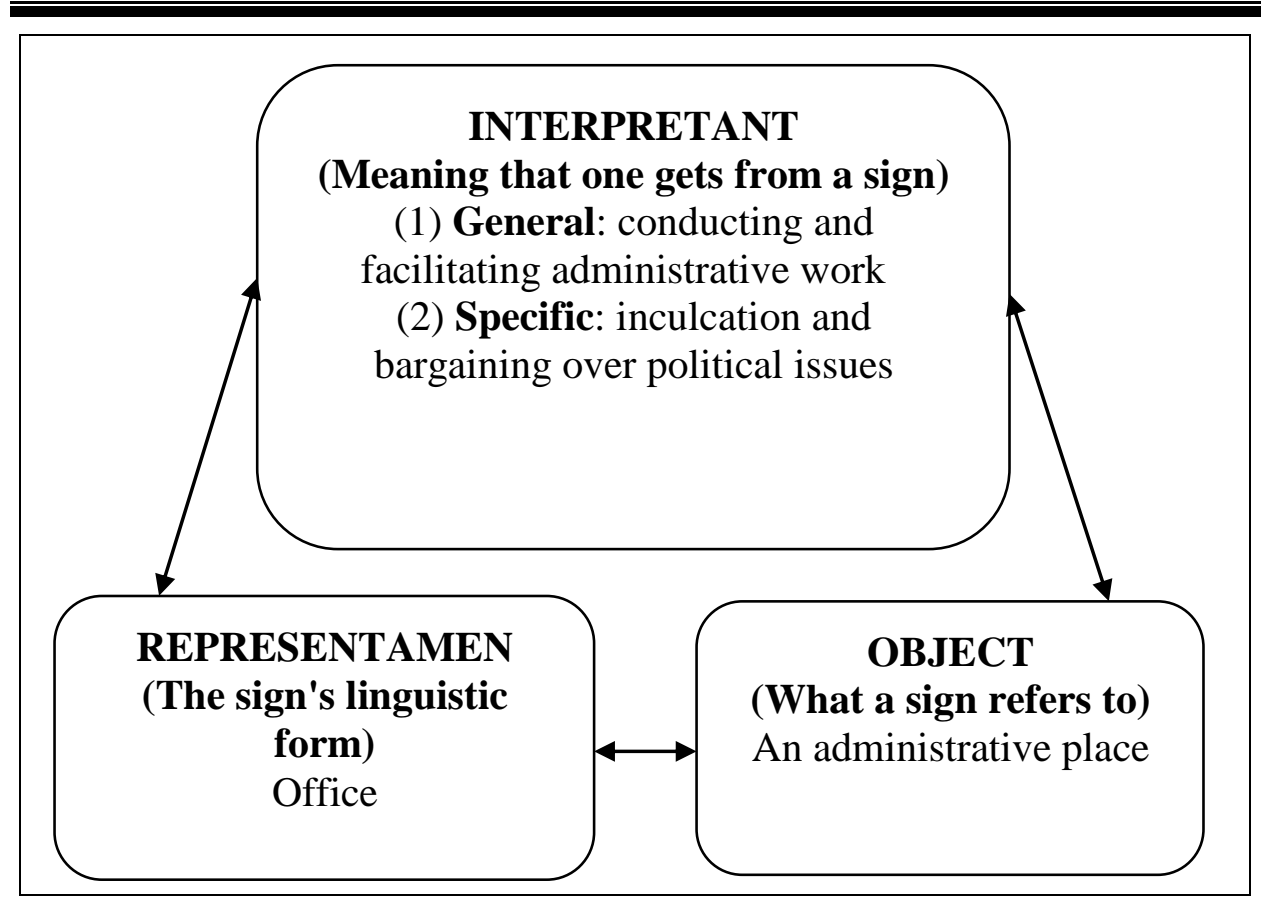

Figure 3. General/specific significations of the sign 'Office' in Peirce's triadic model

The above figure displays that the spatial sign 'Office' has three semiotic elements: a representamen, which is represented by the linguistic form of the word 'Office'; an object, which indicates its referent: an administrative place; and an interpretant, which refers to the sign's different interpretations. As shown above, the sign 'Office' has demonstrated two different interpretations constituting its general and specific significations. The general signification perceives the sign as a place where administrative work is executed, while the specific signification undergoes the meanings of inculcation and bargaining over political issues.

As is the case with the previous two spatial signs, the dramatic dialogue of the play, which is set in the office, has been contextualized to draw the readers'/audience's attention to the

\begin{tabular}{lllll}
\hline \hline ELLS Vol.9 No.I & (43) SPU December 2018
\end{tabular}


specific significations related to the sign 'Office'. The first situation in which the specific significations of the sign 'Office' have been clarified comes when the Doctor tells Alexander: "You are here because you have delusions, that sane people are put in mental hospitals" (EGBDF, p. 27, emphasis in original). The Doctor's words show how facts become 'delusions' under dictator regimes. Everything is justified even if it runs counter to logic, facts, and, sometimes, history. When Alexander says: "I have no symptoms, I have opinions," the Doctor replies: "Your opinions are your symptoms" (EGBDF, P. 30). Alexander's 'delusions' and 'opinions', in the eyes of the government, are justified by the Doctor: "The idea that all the people locked up in mental hospitals are sane while the people walking about outside are all mad is merely a literary conceit, put about by people who should be locked up" (EGBDF, P. 27). Here, the Doctor tries to persuade Alexander that he is insane and needs to be treated in the mental hospital. He proceeds to say that "if you're not prepared to discuss your case rationally, we're going to go round in circles" (EGBDF, P. 27, my emphasis), which, ironically, conveys two things. First, the word 'discuss' here means 'comply' and 'submit'; the Doctor does not want Alexander to discuss his case with him, Alexander already did this but in vain. However, the Doctor's intended discussion targets Alexander's complete submission to the government. Second, the connotative meaning of the word 'rationally' indicates that the Doctor knows for sure that Alexander is completely sane, but his conviction cannot be accepted by the regime. These two things tend to make the readers/audience rethink the signification of the sign 'Office', or to reconsider their "semantic memory" (van Dijk \& Kintsch, 1983, p. 46) so as to accept new ideas relevant to the new context attributed to the sign. To Jappy (2017, p. 158), "the Sign creates something in the Mind of the Interpreter" (emphasis in original). This leads the interpreter to reformulate the semiotic framework of the sign to attribute new significations to its schematic scope.

ELLS Vol.9 No.I
(44) SPU
December 2018 
Continuing with the same semiotic focus that highlights the specific significations of the sign 'Office', Stoppard shows how the dialogue between the Doctor and Alexander has been conducted to reflect the use of the sign 'Office' for political inculcation. This is demonstrated when the Doctor gives Alexander some instructions as follows:

The sort of thing I'd stick to is 'Yes', if they ask you whether you agree you were mad; ' $N o$ ', if they ask you whether you intend to persist in your slanders; 'Definitely', if they ask you whether your treatment has been satisfactory, and 'Sorry', if they ask you how you feel about it all, or if you didn't catch the question. (EGBDF, P. 28, my emphasis)

The above quote displays the direct and clear process of inculcation Alexander undergoes. This is shown through the use of the short answers 'yes', 'no', 'definitely', and 'sorry' that are followed by conditional-if clauses. The Doctor does not want Alexander to speak or discuss any of his issues, but to commit himself only to what he dictates. Importantly, the Doctor's inculcation is faced by Alexander's resistance when the latter says: "I was never mad, and my treatment was barbaric" (EGBDF, P. 28). At this point, the inculcation process changes to take a form of bargaining in which the Doctor tries to communicate a feeling of mutual interest by asking Alexander to cooperate with him: "Stupidity is one thing I can't cure. I have to show that I have treated you. You have to recant and show gratitude for the treatment. We have to act together" (EGBDF, P. 28). Once more, Alexander's refusal to acknowledge that he is mad is described as 'stupidity'. This situation demonstrates the Doctor's conviction that Alexander is sane but he will never let him go unless he says what the regime wants to hear.

Now, the Doctor attempts to intimidate Alexander that they will harm his son: "What about your son? $\mathrm{He}$ is turning into a

\section{ELLS Vol.9 No.I}

(45) SPU

December 2018 
delinquent. He's a good boy. He deserves a father" (EGBDF, 29). Here, a threat is explicitly launched against Alexander's son; the government will change him into a criminal if Alexander does not comply with its orders. Frustrated by what is happening, Alexander expresses his desire to "get back to the bad old times when a man got a sentence appropriate to his crimes" (EGBDF, P. 31). Significantly, the Doctor tries to dissociate himself from the whole situation: "It's not me! I'm told what to do" (EGBDF, P. 31). This emphasizes that he has no control over his actions; he is controlled by the government. This idea is also confirmed through a conversation held at the school between the Doctor and Sacha:

Sacha: He's going to die.

Doctor: I'm not allowed to let him die.

Sacha: Then let him go.

Doctor: I'm not allowed to let him go till he admits he's cured.

Sacha: Then he'll die.

Doctor: He'd rather die than admit he's cured? This is madness, and it's not allowed.

Sacha: Then you'll have to let him go.

Doctor: I'm not allowed to- it's a logical impasse. Did you tell him he mustn't be so rigid?

Sacha: If you want to get rid of papa, you must not be rigid!

(EGBDF, P. 36, my emphasis)

The use of the phrase 'be allowed to' in the negative form in all of the Doctor's above conversational turns indicates that he is subjugated by the government. The conversation above also shows that neither Sacha's father nor the Doctor wants to surrender. This reflects the ideological conflict between two parties: Alexander and his son versus the Doctor as a government representative. These conflicting ideologies, which fail to be reconciled through inculcation, bargaining and intimidation, tend to drive the schematic 


\section{Dr. Ayman F. Khafaga}

wheel of the sign 'Office' towards new specific significations rather than its cognitively encoded ones.

\subsection{The semiotics of the audible sign 'Music'}

Stoppard utilizes the audible sign 'Music' to carry in-play significations that contradict the sign's ordinary out-play meanings. The following figure shows the two dimensions of significations pertaining to the sign 'Music'.

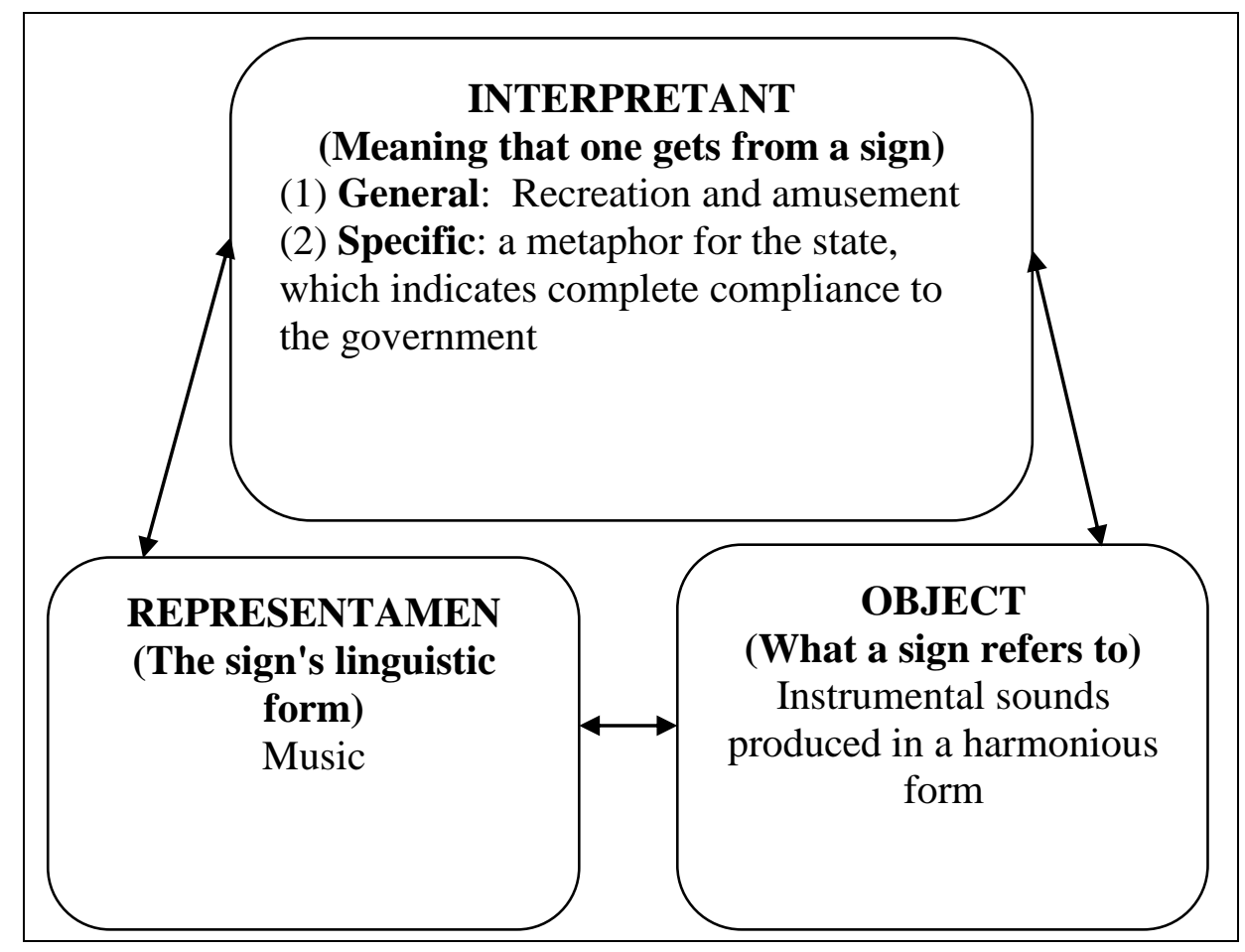

Figure 4. General/specific significations of the sign 'Music' in Peirce's triadic model

The above figure demonstrates three things. First, the audible sign 'Music' has one representamen that is manifested in the linguistic form of the word. Second, it has one referent (object) that refers to any instrumental sounds produced in harmony. Third, the sign 'Music' carries two significations: general, which carries recreational

\section{ELLS Vol.9 No.I (47) SPU December 2018}


significations; and specific, which constitutes the metaphorical use of the sign, that is, the complete compliance to the state.

The specific significations assigned to the sign 'Music' are highlighted through the dramatic dialogue in Stoppard's play. These significations are conveyed in two ways: verbally, through the verbal use of some music-related words that are utilized metaphorically throughout the play; and nonverbally, through the musical performance that accompanies almost all conversations of characters. In both cases, music is employed to achieve political purposes.

An early reference to the metaphorical use of the sign 'Music' is stated by Stoppard in his introduction to $E G B D F$ when he likens the Soviet regime to "an orchestrated society" (EGBDF, P. 7). It is a society that is organized and arranged in a systematic manner like an orchestra. This political symbolism is also emphasized in the character-to-character level of discourse, when Ivanov, addressing Alexander, says: "Not to speak of the glockenspiel" (EGBDF, P. 16). The word 'glockenspiel', which is a musical instrument, can be said to stand for any governmental institution within the Soviet regime. This carries a metaphorical reference that music, with all its instruments, represents the regime, with all its institutions.

The musical metaphor is reflected by Ivanov when he advises Alexander: "Never speak ill of a musician" (EGBDF, P. 18, emphasis in original), which comes in response to the latter's declaration that he is put in the mental hospital "for slander" (EGBDF, P. 18). Again, politicians are likened to musicians and speaking ill of politicians, in the eyes of tyrannical regimes, means insanity that requires imprisonment. This metaphorical use of the sign 'Music' is highlighted by Fransen's (2003, p. 6) words: "The state views its citizens not as freely interacting individuals, but rather as musicians guided by a fixed, written score, and conducted

\section{ELLS Vol.9 No.I}

December 2018 
by the state" (EGBDF, P. 18), and is conversationally enabled by Ivanov's description of musicians (politicians): "They're animals, to a man" (EGBDF, P. 18). Within such a metaphorically musical (political) context, each member in society should commit himself to do what the orchestra (government) dictates, or as Fransen (2003, p. 6) puts it, "each individual has his or her place and is expected to be obedient to whatever the 'music' demands."

Further, the use of the sign 'Music' to represent the state continues to be conversationally expressed in the side of the antisystem characters: Alexander and Sacha. As for Alexander, his insistence: "I don't play an instrument" (EGBDF, P. 17), which is repeated three times in the play, clarifies the reason why he is put in a mental hospital. The inability to play a musical instrument means refusal to submit to the regime's rules. Importantly, this musical metaphor, which spots light on the specific political signification of the sign 'Music', is dramatically toughened in two ways: Alexander's emphasis: "I have never played one [instrument]" and Ivanov's advice to Alexander: "Practice" (EGBDF, P.18). Alexander's words indicate that he was never in accordance with the system, and Ivanov's advice tends to make him involved in the orchestra. Here again, an indirect political indication is conveyed: practicing a musical instrument (compliance to the regime) is the only way Alexander has to escape the system's atrocities.

Similarly, Sacha, who is subject to a sever process of manipulation in the hands of the Teacher, also refuses to be a member of the orchestra: "I don't want to be in the orchestra" (EGBDF, P.19). The political symbolism beyond the word 'orchestra' is highlighted by the Teacher's threat to Sacha: "You see what happens to anti-social malcontent" (EGBDF, P. 19) and is emphasized by Sacha's innocent reply: "Will I be sent to the lunatics' prison?" (EGBDF, P. 19). Now, it is clear that refusing to play an

\section{ELLS Vol.9 No.I}

(49) $S P U$

December 2018 
instrument or to be a member of the orchestra means insanity and imprisonment.

Nonverbally, the specific signification of the audible sign 'Music' is channeled through the rising and falling tone of performance that accompanies some conversations in the play. This is reflected in the written text via the stage directions of the play that are occasionally attached to the end of some turns. A clear example of this can be found in Alexander's description of what happened to his friends. Indicatively, Alexander's description is accompanied by a soft tone of music. However, when Alexander starts to report how he reacted to his friends' arrest, the tone is changed suddenly to be violently high: "The percussion is sabotaged exactly as before but this time by a snare drum being violently beaten" (EGBDF, P. 24). Here, it can be supposed that the high tone of the music, given the fact that it represents the regime, is a kind of warning indicating that it is politically forbidden to express your opinion towards any of the regime's decisions.

The same metaphorical signification of the sign 'Music' is nonverbally communicated in two situations in the last scene. The first situation is shown with the Colonel's first and only appearance in the play. The Colonel's entrance and exist are accompanied by musical performance. Parenthetically, readers are told that "the Colonel's entrance is as impressive as possible. The organ accompanies his entrance" (EGBDF, P. 36) and" the Colonel's exist is almost as impressive as his entrance, also with organ music" (EGBDF, P. 37). Here, the musical performance, which accompanies the Colonel, as a government representative, emphasizes the employment of music in political purposes. The second situation is dramatically introduced near the end of the last scene:

\section{ELLS Vol.9 No.I (50) SPU December 2018}


The Teacher moves into the orchestra. The Doctor moves to the violins taking his instrument and joining in. Ivanov takes his triangle and joins the percussionists and beats the triangle. Sacha comes across to the middle of the platform at the bottom. These directions assume a centre aisle going up the middle of the orchestra towards the organ. Alexander and Sacha move up this aisle, Sacha running ahead. At the top he turns and sings to the same tune as before:

Sacha: (Sings) Papa. Don't be crazy! Everything can be all right!

$(E G B D F$, P. 37)

The above quote confirms that the audible sign 'Music' has a metaphorically political signification contradictory to its ordinary one. The act of joining the orchestra by the Teacher, the Doctor and Ivanov indicates their submissive inclination to the regime. In addition, Sacha's movement towards the middle of the orchestra is a reference that indicates his readiness to be incorporated in it in order to save his father. Sacha's words to his father: 'Don't be crazy! Everything can be all right' is an indirect invitation to his father to join the orchestra, i.e. to accept what the government decides without objection in order to escape fabricated insanity.

\section{Findings \& discussion}

As clarified in the analysis of the selected data, the four selected signs cease to indicate their generally perceived significations and assign specific contradictory ones. These specific significations are linguistically enabled through the employment of different contextualization devices that Stoppard utilizes to change the cognitive set of his readers/audience. Consequently, the four audiospatial signs, when used in their ordinary contexts, carry their common significations that are stored in the readers' schematic framework. However, within the specific semiotic context created in $E G B D F$, the signs' interpretant conveys other significations

\section{$\begin{array}{lllll}\text { ELLS Vol.9 No.I } & \text { (51) SPU December } 2018\end{array}$}


contradictory to what is understood from normal semantic usage. This can be shown in the following table.

Table 2. Out/in-play significations of the four signs and the contextualization devices used

\begin{tabular}{llll}
\hline Sign & $\begin{array}{l}\text { Out-play } \\
\text { signification }\end{array}$ & $\begin{array}{l}\text { In-play } \\
\text { signification }\end{array}$ & $\begin{array}{l}\text { Contextualization } \\
\text { devices }\end{array}$ \\
\hline Cell & $\begin{array}{l}\text { Medical } \\
\text { signification }\end{array}$ & $\begin{array}{l}\text { Oppressive } \\
\text { signification }\end{array}$ & $\begin{array}{l}\text { Intensification } \\
\text { (association and } \\
\text { composition) }\end{array}$ \\
School & $\begin{array}{l}\text { Educational } \\
\text { signification }\end{array}$ & $\begin{array}{l}\text { Manipulative } \\
\text { signification }\end{array}$ & $\begin{array}{l}\text { Justification } \\
\text { Association } \\
\text { Intimidation }\end{array}$ \\
Office & $\begin{array}{l}\text { Administrative } \\
\text { signification }\end{array}$ & $\begin{array}{l}\text { Submissive } \\
\text { signification }\end{array}$ & $\begin{array}{l}\text { Inculcation } \\
\text { Bargaining }\end{array}$ \\
& Recreational & Metaphorical \\
Music & signification & signification & $\begin{array}{l}\text { Simile } \\
\text { Rising/falling tone } \\
\text { of performance }\end{array}$ \\
& & & \\
\hline
\end{tabular}

Table 2 reveals a number of findings as follows:

First, the spatial sign 'Cell', when used in its ordinary contexts, carries medical significations. However, the sign's interpretant, within the specific semiotic context of Stoppard's play, has been shifted to convey a contradictory interpretation as it attributes oppressive significations to the sign. This is linguistically enabled by means of some contextualization devices, including intensification which is realized by association and composition. Significantly, Stoppard's use of the intensification strategies emphasizes the correlation among the four analytical dimensions of
ELLS Vol.9 No.I
(52) SPU
December 2018 
this paper: the semiotic, the cognitive, the dramatic and the discursive.

Second, the interpretative semiotic nature, which is generally associated with the spatial sign 'School' in its common contextual setting, has been changed when it comes to be used in Stoppard's play. Obviously, the sign 'School' has educational significations. However, within the play under investigation, it has been assigned specific significations beyond its cognitively preconceived ones as it attends to indicate oppressive significations that run counter to its supposed out-play meanings. Some contextualization tools, such as justification, association, intimidation, repetition and mathematical argumentation are utilized to communicate the in-play significations of the sign 'School'.

For Foucault (1980), public institutions, such as schools and hospitals constitute the whole structure of society and, thus, the state. These institutions are centers where people are treated and educated. Consequently, they are considered sites of powerknowledge. Stoppard, on targeting the schematic knowledge of these public institutions (i.e. school, hospital within particular ideological agenda), tries not only to change what these institutions semiotically signify, but also to modify the discursive structure of the whole society concerning these public spatial signs.

Third, the semiotics of the spatial sign 'Office' has been moved from the general to the specific. As indicated in table 2 above, it conveys administrative significations when used in its naturally occurring context, i.e. out-play context. However, the same sign carries submissive significations when used within the play's dramatic contexts. These in-play significations contradict what the sign commonly communicates, and have been reallocated through the use of some contextualization strategies, such as inculcation, bargaining and threats.

\section{ELLS Vol.9 No.I}


Fourth, the audible sign 'Music' has recreational significations that can easily be grasped when the sign is used in its out-play context. In Stoppard's play, however, it reflects metaphorical significations that contradict its generally schematic meaning. These in-play significations are channeled to the readers' schematic store of knowledge by virtue of simile as well as the rising and falling tone of performance.

Importantly, the political metaphor, which the sign 'Music' carries, indicates that this sign, for Van Leeuwen (1999), has experiential meaning potential and other meanings derived from associating it with political contexts in real world. He, thus, emphasizes the use of music to communicate political and ideological ideas. Further, the rising and falling tone of music throughout the play is described by Arnheim (1969, p. 117) as "experiential associations," which refer to the act of associating the tone performance of music with the speech event. In $E G B D F$, this is realized by the different musical tones utilized in accordance with the conversations of some characters, such as Alexander and the Colonel. Here, Stoppard manages to link together three things: the dramatic event, the music performance and the underlying semiotic meaning, and, thus, harmonizing the semantic propositions of the play with its intended message. This harmonious connection is also confirmed by Umberto Eco's (1990) emphasis on the necessity of connecting the semantics and the pragmatics of semiotic meanings.

Unlike Fauconnier and Turner (2003) who clarify how two different concepts can share a schematic frame of meaning that blends them together, the findings of this paper show that Stoppard confirms the opposite as he demonstrates how contradictory significations can be assigned to only one concept (sign). Stoppard's ability to append new contradictory meanings to the four signs functions to reformulate the readers' existing schemata. This 
indicates that the cognitive structure of readers is targeted to be reshaped by means of some contextualization devices that aim to achieve cognitive familiarity on their part, which, in turn, makes them ready to attach new conceptualizations to the four signs under investigation. This cognitive flexibility to summon new ideas, which do not reconcile with the existing ones, ultimately leads not only to grasp the semiotically-fixed meanings a sign carries, but to discover and accept new ones as well. The readers' cognitive structures, thus, are always involved in an incessant process of meaning-making, the core concern of cognitive semiotics.

Furthermore, the analysis of the selected data reveals that Stoppard, in his attempt to challenge the cognitive semiotics of the three spatial signs (i.e., Cell, School and Office), goes along with what Fauconneir calls "discourse base space" (cited in Brandt\& Brandt, 2005, p. 224), which, for Brandt and Brandt (2005), incorporates the situation in which discursive acts related to space signs take place. This situation constitutes the basis upon which spatial signs can be interpreted in different manners. This is also referred to by Langacker (1999) who argues that signs situation encompasses three elements: first, the different speech events in which signs operate; second, the participants involved in discourse; and third, the circumstances that circulate these events. In the case of this paper, Stoppard dexterously employs the three elements of Langacker's signs' situation to propose a new world of signification that not only contradicts the ordinary semiotics of the three spatial signs in the play, but also stimulate the cognitive potential of readers/audience towards a semiotic augmentation for the three spatial signs. The signs' contextual world, therefore, is essential in the understanding of their meanings, whether these meanings cope with the sign's conceptual system or contravene it.

Crucially, the contextualization devices, which Stoppard dramatically uses, attempt to provide readers with new information

\begin{tabular}{lllll}
\hline \hline ELS Vol.9 No.I & (55) SPU December 2018
\end{tabular}


that runs counter to their "general store of knowledge" (van Dijk \& Kintsch, 1983, p. 46), and help them extend the semantic framework of the four signs to absorb new significations. Thus, these devices create a cognitive link between the macrostructures (main propositions) and the microstructures (the analytically linguistic details) in Stoppard's EGBDF. This cognitive correlation is described as "contextual relevance" (van Dijk, 1991, 202), which tends, as is the case in $E G B D F$, to orchestrate the relationship between the "overall topics and lower-level details" of discourse (ibid., p. 202).

The analysis also demonstrates that the in-play significations of the four selected audio-spatial signs have been linguistically enabled both verbally (Cell, School, Office, Music) and nonverbally (Music). In both cases, the semiotics of the four signs has dramatically been contextualized to drive the cognitive structure of readers/audience towards new contradictory significations. Further, the findings of this paper, compared to the previous studies reviewed here, expose that it has certain characteristics in common with its previous studies but differs in other aspects. These similarities and differences have been marked both analytically and theoretically.

First, this paper reconciles with Gaines's (2006) study in the sense that both of them show how meanings pertaining to spatial signs are cognitively negotiated. While this negotiability of signs meanings, in the light of this paper, is motivated by a skillful contextualization of the sign's discursive atmosphere, it is totally based on the relevance of other concerns related to the sign itself in Gaines's study. Further, this paper shows an analytical difference with Gaines's study as it uses Peirce's triadic model of signs: representamen, object and interpretant, whereas Gaines employs Pierce's categories of signs: firstness, secondness and thirdness. 


\section{Dr. Ayman F. Khafaga}

Significantly, this difference in the adopted analytical models ultimately leads to dissimilarities in findings between the two papers (see Subsection 2.5).

Second, this paper highlights the same findings of Griffith and Machin's (2014). Both studies accentuate that there are underlying meanings beyond any musical performance. However, this paper differs theoretically from Griffith's and Machin's since it uses a semiotic-cognitive approach to show how the audible sign 'Music' assigns new inconsistent significations, while the latter draws on a Hallidayan functional grammar as a theoretical background for proposing a social semiotic approach to the study of music (see Subsection 2.5).

\section{Conclusion}

This paper presented a linguistic analysis of the contradictory significations of the audio-spatial signs in Tom Stoppard's EGBDF. The analysis of the four signs, i.e. Cell, School, Office and Music revealed that the signification of any linguistic sign is determined by the context in which it is used. The analysis also showed that Stoppard manages, by the dramatic contextualization of the four selected signs, to demarcate the discursive universe of the four signs in order to shift their semiotic focus from its general cognitive scope to its specific one. This has been conducted by contextualizing the dramatic dialogue in a way that serves to achieve the intended semiotic-oriented message of the play. The four linguistic signs go beyond the textual towards the contextual to adopt different significations contradictory to their cognitively schematic meanings.

The analysis of the selected data also demonstrated that signs' significations are not fixed. They, when framed within specific semiotic contexts, are changeable and depend totally on the readers'/audience's interpretation. This does not mean that interpreting the sign's meaning is an attitude-driven process that offers the latitude of attributing new significations to signs.

\section{ELLS Vol.9 No.I}

(57) SPU

December 2018 
However, stretching the interpretative framework of a sign to make it ready to undergo multiple significations ends the concepts of arbitrariness and abstractness of signs' meanings, and reflects the sign's constant readiness to invite new significations that are always governed by a context-driven process of production.

Finally, this study recommends an extensive study of the culture-specific signs (words/concepts), such as Islam, Christianity, Mosque, Church, Quran and Bible by the employment of the semiotic-cognitive approach. This could reveal different significations for these signs, particularly when they are used in different social, political and cultural contexts. This, in turn, might expose some characteristics of what is called culture-oriented semiotics, and might also divulge schematically polarized significations pertaining to these signs.

\section{ELLS Vol.9 No.I (58) SPU December 2018}




\section{References}

Agawu, K. (2009). Music as discourse: Semiotic adventures in romantic music. Oxford University Press.

Antakyalioglu, Z. (2006). Chaos theory and Stoppard's Arcadia. Journal of Istanbul, 3, 87-93.

Arnheim, R. (1969). Visual thinking. Berkeley: University of California Press.

Bauman, R. \& Briggs, C. (1990). Poetics and performance as critical perspectives on language and social life. Annual Review of Anthropology, 19, 59-88.

https://doi.org/10.1146/annurev.an.19.100190.000423

Brandt, L. \& Brandt, P. A. (2005). Making sense of a blend: A cognitivesemiotic approach to metaphor. Annual Review of Cognitive Linguistics 3, 216-249. https://doi.org/10.1075/arcl.3.12bra

Bruss, E. W. (1978). Peirce and Jakobson on the nature of the sign. In Richard W. Bailey, Ladislav Matejka \& Peter Steiner (Eds.), The sign: Semiotics around the world (pp. 81-98). Ann Arbor, MI: University of Michigan Press.

Chandler, D. (2007). Semiotics: The basics. London and New York: Routledge. https://doi.org/10.4324/9780203014936

de Saussure, F. (1916 [1959]). Course in general linguistics (W. Baskin, Trans.). New York: The Philosophical Library, INC.

Eco, U. (1990). The limits of interpretation. Bloomington: Indiana University Press.

Elam, K. (2005). The semiotics of theatre and drama. London \& New York: Routledge, Taylor \& Francis Group.

Esslin, M. (1987). The field of drama. London: Methuen.

Fauconnier, G. \& Turner, M. (2003). Conceptual blending, form and meaning. Recherches en Communcation [Communication Research], 19, 57-86.

\section{ELLS Vo1.9 No.I (59) SPU December 2018}


Fischer-Lichte, E. (1992). The semiotics of theatre (J. Gaines \& D. Jones, Trans.). Bloomington: Indiana University Press.

Foucault, M. (2002). Space, knowledge and power. In James D. Faubion (Ed.) Power: Essential works of Foucault 1954-1984 (R. Hurley \& others, Trans.), Vol. 3, (pp. 349-364). Penguin Books.

Fransen, F. (2003, August). The individual versus the state: The childish politics of Tom Stoppard's Every Good Boy Deserves Favour and Professional Foul with passing references to flow-control devices and water conservation regulations. Paper presented at the annual meeting of the American Political Science Association, Philadelphia, PA. Retrieved from http://citation.allacademic.com/meta/p62579_index.html.

Gaines, E. (2006). Communication and the semiotics of space. Journal of Creative Communications, 1(2), 173-181. https://doi.org/10.1177/097325860600100203

Gordon, C. (Ed.) (1980). Power/knowledge: Selected interviews and other writings 1972-1977 (C. Gordon, L. Marshall, J. Mepham \& K. Soper, Trans.). New York: Pantheon Books.

Griffith, F. \& Machin, D. (2014). Communicating the ideas and attitudes of spying in film music: A social semiotic approach. Sign Systems Studies, 42(1), 72-97. https://doi.org/10.12697/SSS.2014.42.1.04

Gumperz, J. (1982). Discourse strategies. Cambridge: Cambridge University Press. https://doi.org/10.1017/CBO9780511611834

Hartshorne C., P. Weiss \& A. Burks (Eds.) (1931-1958). Collected Papers of Charles Sanders Peirce (Vols. 1-8). Cambridge, MA: Harvard University Press.

Hervey, S. (1982). Semiotic perspectives. London, England: George Allen \& Unwin.

\section{$\begin{array}{llllll}\text { ELLS Vol.9 No.I } & \text { (60) SPU December } 2018\end{array}$}


Hirschberg, S. (1999). Analyzing the rhetoric of Nixon's "Checker's Speech". In S. Hirschberg \& T. Hirschberg (Eds.). Reflections on language (pp. 512-519). New York \& Oxford: Oxford University Press.

Hurst, M. (2016). Slowing down the going-away process: Tom Stoppard and Soviet dissent. Contemporary British History, 30(4), 484504. https://doi.org/10.1080/13619462.2016.1184093

Inskip, C., MacFarlane, A. \& Rafferty, P. (2008). Meaning, communication, music: Towards a revised communication model. Journal of Documentation, 64(5), 687- 706.

https://doi.org/10.1108/00220410810899718

Jappy, T. (2017). Peirce's twenty-eight classes of signs and the philosophy of representation: Rhetoric, interpretation and hexadic semiosis. London \& New York: Bloomsbury Academic Publishing.

Lagopoulos, A. \& Lagopoulou, K. (2014). Semiotics, culture and space. Sign Systems Studies, 42(4), 435-486. https://doi.org/10.12697/SSS.2014.42.4.02

Langacker, W. (1999). Virtual reality. Studies in the Linguistic Sciences, 29(2), 77-103.

McKerrell, S. \& Way, L. (2017). Understanding music as multimodal discourse. In Lyndon C. S. Way \& Simon McKerrell (Eds.) Music as multimodal discourse: Semiotics, power and protest (pp. 1-20). London \& New York: Bloomsbury Academic Publishing.

Merrell, F. (2005). Charles Sanders Peirce's concept of the sign. In Paul Cobley (Ed.), The Routledge companion to semiotics and linguistics (pp. 28-39). London and New York: Routledge.

Mingers, J. \& Willcocks, L. (2017). An integrative semiotic methodology for IS research. Information and Organization, 27(1), 17-36. http://dx.doi.org/10.1016/j.infoandorg.2016.12.001

O'Halloran K. (2003). Critical discourse analysis and language cognition. Edinburgh: Edinburgh University Press.

\begin{tabular}{lllll}
\hline \hline ELS Vol. No.I & (61) SPU December 2018
\end{tabular}


Randviir, A. (2011). Transdisciplinarity in objects: Spatial signification from graffiti to hegemony. Sign Systems Studies, 39(2/4), 88123. https://doi.org/10.12697/SSS.2011.39.2-4.05

Sebeok, T. A. (2001). Signs: An introduction to semiotics, $\left(2^{\text {nd }}\right.$ ed.). University of Toronto Press.

Shortell, T. \& Krase, J. (2010, October16). Place, space, identity: A spatial semiotics of the urban vernacular in global cities. ESA Research Network Sociology of Culture Midterm Conference: Culture and the Making of Worlds. Available at: https://ssrn.com/abstract $=1693110$

Silverman, K. (1983). The subject of semiotics. New York: Oxford University Press.

Simpson, P. (1997). Language through literature: An introduction. London \&New York: Routledge. https://doi.org/10.4324/9780203279175

Stoppard, T. (1978). Every Good Boy Deserves Favor and Professional Foul. New York. Grove Press, INC.

Urciuoli, B. (2009). Talking/not talking about race: The enregisterments of culture in higher education discourses. Journal of Linguistic Anthropology, 19(1), 21-39. https://doi.org/10.1111/j.15481395.2009.01017.x

van Dijk T. A. (1980). Macrostructures: An interdisciplinary study of global structures in discourse, interaction, and cognition. Hillsdale, NJ: Erlbaum.

van Dijk, T. A. (1991). Cognitive context models and discourse. Congressional Record. Proceedings and Debates of the 102d Congress, 137(84), 189-226.

van Dijk, T. A. (1993). Principles of critical discourse analysis. Discourse \& Society, 4(2), 249-283.

https://doi.org/10.1177/0957926593004002006

\section{$\begin{array}{llllll}\text { ELLS Vol.9 No.I } & \text { (62) SPU December } 2018\end{array}$}


van Dijk, T. A. (1995). Discourse analysis as ideology analysis. In Christina Schaffner \& Aneta L. Wenden (Eds.). Language and peace (pp. 17-33). Dartmouth: Aldershot.

van Dijk, T. A. (Ed.) (1997). Discourse as interaction in society. In Discourse as social interaction: Discourse studies: A multidisciplinary introduction, Vol. 2, (pp. 1-37). Sage Publications. https://doi.org/10.4135/9781446221884.n1

van Dijk, T. A. (2001). Multidisciplinary CDA: A plea for diversity. In R. Wodak \& M. Meyer (Eds.), Methods of critical discourse analysis (pp. 95-120). London: Sage.

van Dijk T. A. (2008). Discourse and context: A sociocognitive approach. Cambridge: Cambridge University Press.

https://doi.org/10.1017/CBO9780511481499

van Dijk T. A. (2009a). Society and discourse: How context controls text and talk. Cambridge: Cambridge University Press. https://doi.org/10.1017/CBO9780511575273

van Dijk T. A. (2009b). Critical discourse studies: A sociocognitive approach. In R. Wodak \& M. Meyer (Eds.), Methods of critical discourse analysis ( $2^{\text {nd }}$ ed., pp. 62-86). London: Sage.

van Dijk, T. A. (2014). Discourse and knowledge: A sociocognitive approach. Cambridge University Press.

https://doi.org/10.1017/CBO9781107775404

van Dijk, T. A. \& Kintsch, W. (1983). Strategies of Discourse Comprehension. New York: Academic Press

van Leeuwen, T. (1999). Speech, music, sound. London: Macmillan. https://doi.org/10.1007/978-1-349-27700-1

van Leeuwen, T. (2009). Discourse as the recontextualization of social practice: A guide. In R. Wodak \& M. Meyer (Eds.), Methods of Critical Discourse Analysis (pp. 144-161). Thousand Oaks: Sage.

Whitmore, J. (1994). Directing postmodern theater. Ann Arbor: The University of Michigan Press. https://doi.org/10.3998/mpub.23644

\section{$\begin{array}{llllll}\text { ELLS Vol.9 No.I } & \text { (63) SPU December } 2018\end{array}$}


Contradictory Significations of the Audio-Spatial Signs in Tom Stoppard's Every Good Boy Deserves Favor: A Semiotic-Cognitive Approach

Žemaityte, G. (2017). Plastic semiotics: From visuality to all the senses. Sign Systems Studies, 45(1/2), 152-161.

https://doi.org/10.12697/SSS.2017.45.1-2.10 